\title{
ANALISIS PROBLEMATIKA PENDIDIKAN MATEMATIKA BERUPA SOAL CERITA PADA SISWA SD
}

\author{
Satrio Wicaksono Sudarman \\ Pendidikan Matematika FKIP Universitas Muhammadiyah Metro \\ E-mail: rio_sudarman@yahoo.com
}

\begin{abstract}
this study is intended to determine problemtika types of errors in math story problem solving in elementary school student. This type of research is descriptive qualitative research. In a descriptive study is essentially a method used to find specific data and the reality of what happened in the community at a particular time. To find the errors do math word problems can be analyzed on a step by step process of the students completed the test questions were given. in some cases comprehension students about about the story on which this study, students' difficulties phrased sentence of math word problems, difficulty in terms of actual in description story for students in the following ways; (1) Students with lower language understanding, it is very difficult to digest towards the goal of every sentence in the matter of the story. Going where and what to do with the sense of the question is very vague and unclear. So the mindset of students just spinning on the same premises. (2) The concept is not yet strong prerequisite for solving problems related to the concept of prerequisite
\end{abstract}

Keywords: stories about the problematics of math $S D$

\section{PENDAHULUAN}

Pandangan masyarakat tentang pelajaran matematika merupakan pelajaran yang sulit dan menakutkan adalah hal yang cukup beralasan. sebagian besar siswa khususnya di Indonesia, pembelajaran matematika selama ini belum mampu mengubah ranah afektif dan kognitif siswa menuju yang lebih baik. Hal ini terkait dengan peryataan, Bosse dkk. (2012) bahwa siswa menunjukkan kesulitan dalam melakukan penterjemahan matematis dan representasi matematis.

Dari hasil wawancara dengan beberapa guru dan siswa SD $\mathrm{N} 4$ Yosodadi, diperoleh informasi bahwa dalam praktik pembelajaran matematika di kelas, seringkali guru dihadapkan pada kenyataan bahwa sebagian besar siswa mengalami kesulitan dalam menyelesaikan soal cerita matematika, siswa tidak berani menanyakan hal yang menjadi kesulitannya dalam belajar matematika, pelajaran matematika dan khususnya soal cerita matematika bagi sebagian besar siswa merupakan hal yang menakutkan, jarang ditemukan ideide baru dari siswa dalam menyelesaikan soal cerita matematika, serta bagi beberapa guru merancang dan memilih masalah matematika yang kontekstual masih merupakan hal yang sulit.

Menurut guru di kelas tinggi (kelas IV, V, dan VI), masalah yang terkait dengan soal cerita matematika telah dialami siswa sejak mereka duduk di kelas rendah (kelas I, II, dan III). Hal ini selain disebabkan oleh keadaan di mana pada waktu kelas I dan II, soal cerita masih dibuat kontekstual dengan menggunakan benda-benda di sekitar siswa dan soal masih dibacakan oleh guru. Siswa belum mampu diajak berpikir abstrak dan pemahaman dalam membaca masih sangat kurang. Ini berarti dengan adanya kenyataankenyataan tersebut bagi siswa kelas tinggi, ketidakmampuan menyelesaikan 
soal cerita matematika telah berlangsung dalam kurun waktu yang relatif lama. Selanjutnya terungkap bahwa secara umum letak kesulitan siswa dalam menyelesaikan soal cerita matematika adalah menemukan bentuk operasi bilangan yang harus digunakan, dalam hal ini cara atau metode dan beberapa siswa mengalami kesulitan dalam menalar bentuk soal-soal cerita karena kurang pemahaman dalam membaca dan intonasi membaca.

Terkait dengan masalah di atas, faktor lain yang menambah kesulitan siswa adalah pembelajaran matematika yang sering dilakukan guru dengan menggunakan model klasikal dengan metode ekspositori dan pendekatan mekanistik, yaitu algoritma aritmatika dan rumus matematika diinformasikan dan dilatihkan melalui tugas kepada siswa, dan diakhiri dengan melatihkan aplikasinya baik dalam soal-soal bilangan maupun dalam soal cerita matematika. Secara garis besar, situasi pembelajaran menggambarkan suatu kegiatan guru aktif memberikan informasi, sedangkan siswa menyimak, mencatat dan mengerjakan tugas.

\section{METODE PENELITIAN}

penelitian deskriptif-kualitatif,

Sukmadinata (2011:72)

menjelaskan Penelitian deskriptif adalah suatu bentuk penelitian yang ditujukan untuk mendeskripsikan fenomena yang ada, baik fenomena alamiah maupun fenomena buatan manusia. karena pada penelitian ini berusaha mengidentifikasi berpikir analisis siswa siswa dalam menyelesaikan masalah yang berkaitan dengan soal cerita. Dalam penelitian deskriptif pada hakekatnya merupakan metode yang digunakan untuk menemukan data yang spesifik dan realitas yang terjadi dalam masyarakat pada waktu tertentu. Untuk mengetahui kesalahan proses mengerjakan soal cerita matematika dapat dianalisis pada proses tahap demi tahap siswa tersebut menyelesaikan soal tes yang diberikan.

Untuk memeriksa keabsahan data diperlukan Teknik Pemeriksaan Keabsahan Data. Adapun mengenai "Teknik Pemeriksaan Keabsahan Data", didasarkan atas sejumlah KriteriaKriteria Keabsahan Data. Oleh karena itu, usaha-usaha peneliti untuk pengecekan keabsahan data menggunakan teknik-teknik: Perpanjangan keikutsertaan, Ketekunan pengamatan, (3) Triangulasi, (4) Pemeriksaan teman sejawat melalui diskusi.

1. Perpanjangan Keikutsertaan

$\begin{array}{crr}\text { Pada } & \text { penelitian } & \text { kualitatif } \\ \text { keikutsertaan } & \text { peneliti } & \text { sangat }\end{array}$ menentukan dalam pengumpulan data, Karena Sebab Perpanjangan Keikutsertaan di dalam pengumpulan data akan memungkinkan kredibilitas data yang dikumpulkan.

2. Ketekunan Pengamatan

Ketekunan pengamatan bertujuan untuk menemukan ciri-ciri dan unsurunsur dalam situasi yang sangat relevan dengan persoalan atau isu yang sedang dicari dan kemudian memusatkan diri pada hal-hal tersebut secara rinci. Untuk itu peneliti akan melakukan pengamatan dengan cermat dan teliti

3. Triangulasi

Triangulasi merupakan teknik pemeriksaan keabsahan data yang memanfaatkan sesuatu yang lain di luar data itu untuk keperluan pengecekan atau sebagai pembanding terhadap data itu. Penelitian ini juga menggunakan triangulasi pengecekan dengan sumber melalui catatan-catatan lain pada waktu dan alat yang berbeda.

4. Pemeriksaan Teman Sejawat melalui Diskusi

Pada tahap ini dapat dilakukan dengan cara Melakukan perbandingan, 
pengecekan kebenaran dan kesesuaian data penelitian melalui diskusi analitik dengan rekan-rakan sejawat dimana dalam hal ini diskusi antara teman yang mempunyai pengetahuan tentang problematika siswa sd dalam mengerjakan soal cerita.

Teknik pengumpulan data yang dilakukan adalah untuk mengidentifikasi kesalahan dalam mengerjakan soal cerita yaitu dengan menganalisis hasil tes yang diberikan kepada siswa. Lokasi penelitian menggunakan metode purposive area. Penelitian ini dilaksanakan di SD Negeri 4 Metro Timur. Teknik pengumpulan data yang digunakan dalam penelitian ini antara lain tes, angket, wawancara, observasi dan dokumentasi.

Sebelum soal-soal tes dijadikan instrumen penelitian, tes tersebut diuji validitasnya dan reliabilitas. berdasarkan hasil pengujian uji validitas isi dan muka dilakukan oleh para ahli yang berkompeten, yaitu 2 orang guru bidang studi matematika. Berdasarkan hasil uji coba terbatas, diperoleh gambaran bahwa semua soal tes dipahami dengan baik diperoleh koefisien reliabilitas instrumen tes sebesar 0,72 sehingga instrumen tes tersebut dapat digunakan.

\section{HASIL PENELITIAN DAN PEMBAHASAN}

\section{A. Soal Cerita Matematika}

Dalam pembelajaran matematika

di SD, kemampuan menyelesaikan masalah yang berkaitan dengan kehidupan sehari-hari diperoleh melalui pembelajaran pemecahan masalah matematika berbentuk soal cerita (selanjutnya disebut soal cerita matematika). Soal cerita matematika di SD dikemas dalam bentuk cerita dari kehidupan sehari-hari. Keberadaannya dimaksudkan agar siswa tidak hanya mampu mengaplikasikan matematika dalam kehidupan sehari-hari, tetapi juga sebagai sarana mendorong munculnya sikap positif siswa terhadap matematika dengan memperlihatkan kebermaknaan matematika dalam kehidupan sehari-hari siswa.

Soal cerita matematika di SD dapat digolongkan berdasarkan arti kalimat dan situasi soal. Nesher dalam Ahmad, Tarmizi, dan Nawawi (2010) menyatakan bahwa penyelesaian soal cerita merupakan salah satu komponen penting dari penyelesaian masalah matematika yang menggabungkan masalah kehidupan nyata dan aplikasi.

B. Kesulitan Belajar Matematika

Matematika sebagai salah satu mata pelajaran yang diajarkan di sekolah dasar mempunyai posisi yang sangat penting, sebab di samping dapat memberi bekal kemampuan berhitung, juga dapat memberi bekal kemampuan menalar. Pada pendidikan dasar matematika tergolong mata pelajaran yang dirasakan sulit bagi siswa, karena matematika ditinjau dari segi objeknya bukanlah merupakan objek konkret tetapi merupakan benda pikiran seperti yang dikemukakan Polya (2007) bahwa pemecahan masalah dalam matematika terdiri atas empat langkah pokok, yaitu: memahami masalah, membuat rencana untuk menyelesaikan masalah, melaksanakan penyelesaian soal, memeriksa ulang jawaban yang diperoleh.

Dengan memperhatikan

karakteristik matematika di atas, tidak mustahil jika siswa dalam mempelajari matematika mengalami kesulitan. Kesulitan itu dapat terlihat dalam proses pemecahan soal-soal matematika. Berkaitan dengan hal ini penelusuran kesalahan siswa dalam menyelesaikan soal dilakukan dengan mendeteksi kesulitan siswa dalam belajar matematika. Huang (2012) menyatakan bahwa keterampilan pemecahan masalah 
yang baik adalah kunci untuk memperoleh solusi sukses dalam matematika. Hasil penelitian ini dapat dimaknai bahwa keterampilan pemecahan masalah perlu dikembangkan untuk dapat menyelesaikan suatu persoalan dalam matematika., selain itu terdapat menafsirkan dan menyampaikannya.

Soal cerita sebagai bentuk aplikasi dari konsep matematika merupakan suatu hal yang sangat penting dalam matematika sekolah yang diajarkan disetiap jenjang pendidikan. Pengerjaan soal cerita yang dipelajari di sekolah dasar selain sebagai bekal belajar lebih lanjut, juga bermanfaat tujuan formal dalam pengajaran matematika. Tetapi kenyataannya di lapangan khususnya di sekolah dasar masih dijumpai siswa yang mendapat kesulitan dalam mengerjakan soal cerita matematika yang merupakan soal yang selalu dianggap sulit bagi siswa sekolah dasar.
Otilia
C. Barbu
(2010)

menyatakan bahwa kompleksitas bahasa memiliki pengaruh yang besar terhadap persepsi siswa dalam memecahkan masalah matematika. Hasil penelitian ini dapat dimaknai bahwa penggunaan bahasa dalam soal berpengaruh terhadap siswa dalam memahami soal cerita matematika.

. Proses kegiatan analisis data kualitatif dalam penelitian ini dilakukan dengan tahap tahap sebagai berikut. (1) Mereduksi data. Reduksi data adalah kegiatan yang mengacu pada proses menyeleksi, memfokuskan, menyederhanakan, mengabstrasikan, dan mentrasformasikan data mentah yang tertulis pada catatan lapangan. (2) penyajian data. Penyajian data merupakan sekumpulan informasi/ data yang teroganisasi dan terkategori dituliskan kembali, sehingga memungkinkan untuk menarik kesimpulan dari data tersebut. (3)
Penarikan kesimpulan. Setelah data terkumpul maka dilakukan penarikan kesimpulan/verifikasi yaitu kegiatan merangkum data berdasarkan semua hal yang

terdapat dalam reduksi data dan penyajian data. Untuk kegunaan penelitian perlu terlebih dahulu melihat hasil tes pekerjaan siswa yang tertera pada table 4.1 berikut

Tabel 1 Deskriptif Data Kemampuan Siswa Menyelesaikan Soal Cerita dan soal Operasional Biasa Matematika

\begin{tabular}{|c|c|c|c|c|}
\hline & \multicolumn{2}{|c|}{ Nilai } \\
\hline & & & $\begin{array}{c}\text { Soal } \\
\text { Operasional } \\
\end{array}$ & $\begin{array}{c}\text { Soal } \\
\text { Cerita }\end{array}$ \\
\hline 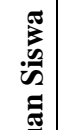 & Rendah & $\begin{array}{l}\text { Indah } \\
\text { Lestari }\end{array}$ & 75 & 35 \\
\hline 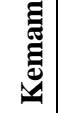 & Tinggi & $\begin{array}{l}\text { Widya } \\
\text { Cantika }\end{array}$ & 100 & 60 \\
\hline
\end{tabular}

Dari data yang diperoleh menunjukkan bahwa ada suatu rentang nilai yang cukup besar antara siswa yang diberikan soal operasional biasa dengan soal cerita, baik pada siswa yang memiliki kemampuan rendah maupun kemampuan tinggi. Pada siswa dengan kemampuan rendah (Indah Lestari) ketika diberikan soal opersional biasa memperoleh nilai 75 , kemudian diberikan soal cerita dengan jumlah soal yang sama ternyata terjadi penurunan nilai yang cukup drastis. Ada penurunan nilai 40 poin dari nilai awal. Hal serupa juga di alami oleh siswa yang memiliki kemampuan tinggi (Widya Cantika). Pada awalnya siswa memperoleh skor 100 saat diberikan soal opersional biasa. Namun, setelah diberikan soal cerita turun 40 poin (Tabel 1).

Kejanggalan akibat penurunan poin yang terjadi belum menjawab apa dan mengapa penurunan poin tersebut terjadi. Ternyata dari deskripsi nilai 
tersebut peneliti hanya mendapatkan hasil nilai dari pengerjaan soal dan dapat di analisis bahwa dari skor terlihat adanya kesulitan dalam pengerjaan soal cerita. Sesuai dengan pertanyaan penelitian yang telah dikemukakan sebelumnya, maka untuk menjawab pertanyaan penelitian tersebut, dilakukan pembahasan dan analisis jawaban siswa untuk mengungkap letak, dan jenis kesalahan jawaban atau kesulitan setiap siswa yang dijadikan subyek penelitian.

\section{Analisis Kesalahan Subyek Dengan Kemampuan Rendah Untuk Soal Cerita}

Dari 4 soal yang dikerjakan, subyek (Indah Lestari) melakukan kesalahan dalam menjawab soal nomor 1, 3, dan 4 seperti pada uraian berikut.

\section{Hasil Kerja Soal Nomor 1}

Dari hasil tes dan wawancara (lihat wawancara), diketahui bahwa subyek melakukan kesalahan karena "kesulitan dan tidak teliti dalam menganalisa soal" untuk menyelesaikan soal nomor 1. Siswa cenderung tidak memperhatikan kata-kata "pulang pergi”, yang berarti bahwa pekerjaan tersebut dilakukan dua kali dan jarak yang di tempuh harus dikalikan dua. Peneliti kemudian mendapatkan suatu kesalahan penguasaan konsep prasyarat. Terlihat pada soal $1 \mathrm{~b}$, siswa menjawab "3200", ini mengindikasikan siswa belum menguasai konsep perkalian yang telah diajarkan pada kelas tiga. Hal ini diperkuat dengan hasil wawancara dengan siswa yang mengaku masih kesulitan saat mengalikan bilangan "300 dengan 7"(lihat wawancara). Demikian halnya dengan penulisan satuan, di mana subyek tidak menuliskan pada jawaban.

* Soal :

Setiap hari Bu Dina belanja ke pasar naik mobil. Jarak rumah dan

pasar $2 \mathrm{~km}$ lebih $300 \mathrm{~m}$. a) Berapa jarak yang di tempuh bu Dina pulang pergi dari rumahnya

ke pasar dalam sehari?

b) Berapa jarak yang di tempuh bu Dina pulang pergi dari rumahnya ke pasar dalam seminggu ?

\section{* Jawaban Subyek (IndahLestari):}

a) Diketahui : jarak rumah-pasar $=2 \mathrm{~km}$ lebih $300 \mathrm{~m}$

Maka jarak yang di tempuh sehari $=2 \mathrm{~km}$.

b) Diketahui : jarak rumah-pasar $=2 \mathrm{~km}$ lebih $300 \mathrm{~m}$

Maka jarak yang di tempuh seminggu $=2 \mathrm{~km}$ lebih $300 \mathrm{~m} \times 7$ $=3200$

\section{Wawancara (Indah Lestari) :}

Untuk mengetahui penyebab kesalahan yang dilakukan subyek (S) diberikan petikan wawancara oleh peneliti $(\mathrm{P})$ sebagai berikut.

$\mathrm{P} \quad$ : "Coba dibaca soal baik-baik soal nomor 1".

$\mathrm{S} \quad$ : (membaca soal)

$\mathrm{P} \quad$ : "Bisa mengerti soalnya? Apa yang diketahui dalam soal itu, Indah?'

S : "Bisa pak, diketahui jarak rumah-pasar $=2 \mathrm{~km}$ lebih 300 m"

P : "Bagus, sekarang apa pertanyaan yang diketahui dalam soal, Indah?"

S : "Pertama, jarak yang di tempuh dari rumah ke pasar sehari dan yang kedua jarak yang di tempuh dari rumah ke pasar seminggu."

P : "Bagus, coba dibaca sekali lagi. Ada yang kurang atau tidak dari pertanyaan soalnya, Indah?"

S : (membaca soal)

P : "Bagaimana?"

S : "Tidak ada pak" 
P : "Oke, Indah lupa membaca pulang pergi. Apa artinya?"

S : Diam (tidak mengerti)

P : "Oke, tidak apa-apa. Sekarang coba lihat pekerjaan Indah nomor $1 \mathrm{~b}$ ?"

$\mathrm{S}$ : (membaca pekerjaan)

P : "Dari mana jawaban 3200, Indah?"

S : "Hasil kali dari 300 dengan 7, Pak"

P :"Oke, apa satuannya?"

$\mathrm{S}$ : Diam (tidak mengerti).

\section{Hasil Kerja Soal Nomor 3}

Pada pengerjaan soal nomor tiga, subyek benar-benar kebingungan dalam menentukan arah soal tersebut. Selain karena "soalnya terlalu panjang"(lihat wawancara), subyek ternyata hanya mengerti maksud dari soal tetapi tidak mengerti pertanyaan yang dimaksud. Pada soal nomor 3a, subyek membayangkan bahwa satuan karung merupakan satuan yang sama dengan ukuran ton. Hal ini menunjukkan konsep yang sangat buruk tentang pengukuran berat. Selain tidak mengerti maksud dari soal karena kesulitan dalam mencerna bahasa soal, subyek juga tidak mengerti membahasakan ke dalam matematika. Sebagai contoh pada soal $3 \mathrm{~b}$, siswa tidak paham bahwa kata-kata "tinggal berapa" pada soal yang merupakan bahasa lain dari sisa atau selisih, selain itu siswa tidak tahu menggunakan konsep atau rumus yang mana (lihat wawancara). Sehingga subyek tidak menjawab soal tersebut.

\section{Soal :}

Sebuah truk membawa 250 karung beras dari gudang untuk dikirim ke toko-toko beras. Setiap karung beras beratnya $50 \mathrm{~kg}$. Di toko pertama diturunkan 150 karung, di toko kedua diturunkan 70 karung.

a) Mula-mula berapa ton beras yang di bawa truk tersebut dari gudang?

b) Sekarang tinggal berapa kuintal yang ada di atas truk?

* Jawaban Subyek (Indah Lestari) :

a) Diketahui : Truk membawa 250 karung beras

truk $=250$ ton

beras yang di bawa

b) Diketahui : Truk membawa 250 karung beras

Wawancara (Indah Lestari) :

P : "Sekarang coba baca soal nomor 3, Indah"

$\mathrm{S}$ : (membaca soal)

$\mathrm{P}$ : "Mengerti apa maksud soal itu, Indah?'

S : "Tidak begitu. Soalnya terlalu panjang pak. Tapi nomor 3a ditanya banyaknya beras yang dibawa truk.

P : "Ya, benar. Lalu apa jawabanmu?"

$S$ : "250 ton"

P : "Apakah karung = ton?"

S : "Ehm...iya pak"

$\mathrm{P}$ : "Oke, sekarang nomor $3 \mathrm{~b}$. Bagaimana kalimat matematikanya, Indah?"

S : "Tidak tahu pak"

P : "Kata-kata tinggal berapa di soal apa maksudnya Indah?"

$\mathrm{S}$ : Diam .....(tidak mengerti)

$\mathrm{P}$ : "Kira-kira nomor 3b, menggunakan rumus apa Indah?"

$\mathrm{S}$ : (Menggelengkan kepala)

\section{Hasil Kerja Soal Nomor 4}

Pengerjaan pada nomor 4 terlihat bahwa subyek masih melakukan kebenaran walaupun pada akhirnya tetap salah. Hal ini dikarenakan subyek merasa bahwa soal nomor 4 lebih mudah 
dibandingkan nomor lain. Subyek mengungkapkan soal nomor 4 dikerjakan karena melihat pendeknya soal daripada soal lain (lihat wawancara). Ternyata bagi subyek, visual atau tampilan ikut berpengaruh . Subyek memandang soal nomor 4 lebih mudah karena soalnya yang pendek. Selain itu, terdapat kesalahan pengerjaan pada akhir pengerjaan. Terlihat bahwa dalam pengerjaan pengukuran waktu, subyek belum memahami konsep perkalian dalam bilangan jam. Subyek melakukan kesalahan dengan melakukan perkalian biasa pada bilangan berkoma. Titik pada bilangan jam di anggap sebagai koma. Pengerjaan seharusnya satuan jam di konversikan ke dalam satuan menit lalu dikalikan dengan tujuh dan dikonversikan lagi ke dalam satuan jam.

* Soal :

Mulzam setiap malam belajar pukul 19.00 sampai dengan pukul 21.30. Berapa

jam dalam seminggu Mulzam belajar?

Jawaban Subyek (Indah Lestari) : Mulzam belajar $=21.30$ 19.00

02.30 jam

Jadi seminggu $=7 \times 02.30$

$$
=16.10 \mathrm{jam}
$$

Wawancara (Indah Lestari) :

P : "Bagaimana dengan soal nomor 4 Indah?"

S : "Soalnya lumayan pendek pak"

P : "Apa jawabanmu, coba dilihat"

$\mathrm{S}$ : "Saya kurangkan jamnya pak. Terus karena dalam seminggu saya kalikan 7."

P : "Indah tahu apa arti titik diantara bilangan pada bilangan jam?"

$\mathrm{S}$ : Diam
$\mathrm{P}$ : "Oke, bagaimana cara Indah mengalikan bilangan jam?"

S : "Saya kalikan 7 dengan 2 koma $30 "$

2. Analisis Kesalahan Subyek Dengan Kemampuan Tinggi Untuk Soal Cerita

Dari 4 soal yang dikerjakan, subyek (Widya Cantika) melakukan kesalahan dalam menjawab soal nomor 2 dan 3 seperti pada uraian berikut.

Hasil Kerja Soal Nomor 2

Pada kasus subyek dengan kemampuan tinggi, berdasarkan hasil tes dan wawancara (lihat wawancara) diketahui bahwa subyek melakukan kesalahan karena kesulitan mencerna soal sehingga menyebabkan subyek bingung dalam mebahasakan ke dalam bentuk matematika. Konsep perkalian sudah dikuasai oleh subyek yang menandakan bahwa subyek telah menguasai konsep prasyarat. Hasil wawancara mengungkap lebih detail bahwa subyek bingung dengan mengatakan "akan diapakan" angka dua yang menentukan jenis kue. Sehingga subyek berpikir mengalikannya. Padahal seharusnya tidak, karena "2 jenis" di sini hanya sebagai pengecoh dan tidak perlu ikut dikalikan serta hanya membedakan kue jenis satu dan kue jenis dua.

* Soal :

$\mathrm{Bu}$ Retno membawa 2 jenis kue. Jenis pertama ada dalam 6 kotak kecil dan jenis kedua ada dalam 2 kotak besar. Satu kotak kecil beratnya 300 gram dan satu kotak besar beratnya 600 gram. Berapa kilogram kue yang di bawa bu Retno?

Jawaban Subyek (Widya Cantika) : Diketahui : 2 jenis kue. 6 kotak kecil dan 2 kotak besar

Kue Kotak kecil $=6$ x 300gr $=1800$ gr 
Kue kotak besar $=2 \times 600$ gr $=1200$ gr

Kue seluruh $=2 \times(1800+1200)=2$ $\mathrm{x} 3000=6000 \mathrm{gr}=6 \mathrm{~kg}$

\section{Wawancara (Widya Cantika) :}

$\mathrm{P}$ : "Bagaimana Widya dengan pekerjaanmu nomor 2 ?"

S : "Salah Pak"

P : "Apa jawabanmu, coba dilihat"

S : "6 kg pak."

P : "Dari mana Widya bisa dijelaskan ?"

S : "Pertama, cari berat kue kotak kecil lalu berat kue kotak besar. Dijumlahkan dan dikalikan dengan 2"

P : "Kenapa dikalikan dua?"

$\mathrm{S}$ : "Iya pak saya juga bingung mau diapakan angka dua dalam soal"

\section{Hasil Kerja Soal Nomor 3}

Pada soal nomor tiga subyek sebenarnya mengerti apa yang dimaksudkan soal bahkan untuk nomor 3a, subyek mengerjakannya dengan benar. Pada soal nomor 3b, subyek mengerti namun subyek bingung mau membahasakan ke dalam kalimat matematikanya. Subyek telah menuliskan kata-kata "sisa" yang mencirikan dia mengerti tetapi langkah awal apa yang harus ia ambil untuk menentukan sisa tersebut. Pada soal ini, subyek tidak mengalami kesalahan konsep dan konsep prasyarat juga telah dikuasai.

\section{* Soal :}

Sebuah truk membawa 250 karung beras dari gudang untuk dikirim ke toko-toko beras. Setiap karung beras beratnya $50 \mathrm{~kg}$. Di toko pertama diturunkan 150 karung, di toko kedua diturunkan 70 karung.
a) Mula-mula berapa ton beras yang di bawa truk tersebut dari gudang?
b) Sekarang tinggal berapa kuintal yang ada di atas truk?

* Jawaban Subyek (Widya Cantika) :

a) Diketahui : Truk membawa 250 karung beras, 1 karung $=50 \mathrm{~kg}$ beras yang dibawa truk $=250 \mathrm{x}$ $50 \mathrm{~kg}=12500 \mathrm{~kg}=12,5$ ton

b) Diketahui : 150 karung untuk toko pertama, 70 karung untuk toko kedua.

Sisa

\section{* Wawancara (Widya Cantika) :}

P : "Sekarang coba baca soal nomor 3, Widya"

$\mathrm{S}$ : (membaca soal)

$\mathrm{P}$ : "Mengerti apa maksud soal itu, Widya?"

S :"Ya, pak."

$\mathrm{P}$ : "Bagaimana dengan nomor 3b, mengapa tidak di jawab?"

$\mathrm{S}$ : "Saya tahu pak maksudnya. Tapi saya bingung mau mulai dari mana. Kalau tidak salah itu ditanya sisanya. Saya kadang jadi malas pak mau baca soalnya karena agak panjang."

Dari semua siswa yang diberikan soal cerita terdapat kecenderungan penurunan nilai. Hal ini disebabkan oleh sulitnya menentukan arah tujuan soal, penalaran siswa dalam menerjemahkan bahasa khususnya soal cerita ke dalam bahasa matematika yang begitu sulit, kesalahan penggunaan konsep dan prinsip serta kurang memadainya konsep prasyarat yang dimiliki siswa.. Pada soal cerita seorang siswa selain dihadapkan pada konsep-konsep matematika mereka juga harus memiliki daya nalar yang tinggi dan pemahaman bahasa yang baik. Terkadang seorang siswa hanya memiliki sedikit konsep matematika (konsep prasyarat), yang kemudian dengan konsep yang sedikit tersebut siswa menyelesaikan soal, walaupun hasilnya masih dapat dikatakan cukup. Namun, ketika harus mengerjakan soal cerita, mereka bukan lagi hanya 
terkendala pada konsep matematika dan prinsip tetapi juga penalaran dan bahasa. Penalaran seorang siswa tidak termunculkan karena kurang adanya ideide yang dapat dikaitkan antara satu dengan ide yang lain. Ide-ide tersebut biasanya akan muncul jika seorang guru dapat membawa suasana pembelajaran pada kondisi nyata di lapangan serta perlu adanya stimulus dari guru untuk membangun pola pikir dan ide-ide. Ide tersebut yang akan sedikit demi sedikit mengubah kesan negatif tentang soal cerita dan ketakutan atau kemalasan siswa mengerjakan soal cerita.

Kesulitan dalam soal cerita bagi siswa sebenarnya terdeskripsi dalam beberapa hal berikut :

a. Siswa dengan pemahaman bahasa rendah, sangat sulit mencerna arah tujuan dari tiap kalimat pada soal cerita. Akan kemana dan diapakan pengertian dari soal tersebut sangat kabur dan tidak jelas. Sehingga pola pikir siswa hanya berputar-putar pada pemikiran yang sama.

b. Konsep prasyarat yang belum kuat untuk menyelesaikan soalsoal yang berkaitan dengan konsep prasyarat.

c. Pemahaman konsep matematika yang rendah, menyebabkan siswa sulit menentukan konsep mana yang harus digunakan dalam sebuah soal cerita. Hal ini karena biasanya siswa sudah terlebih dahulu ter-abstraksi dalam teori teori dan rumus sehingga dalam penerapannya abstraksi siswa akan pecah dengan masalah baru yang dihadapi secara aplikatif. Kesalahan memang bukan hanya ada pada siswa tetapi cenderung pada pengonstruksian pola pikir yang kurang tepat.

d. Kurangnya pengalaman dalam mengonstruksi pola pikir juga termasuk kesulitan siswa. Siswa tidak terbiasa untuk menyelami soal-soal aplikatif yang berbau soal cerita.

e. Kesan negatif terhadap soal-soal cerita yang terlihat memiliki kalimat yang panjang sehingga siswa merasa malas bahkan tidak jarang merasa takut sebelum menyelesaikan soal tersebut.

f. Ceroboh dalam pengerjaan soal yang tercermin pada pengerjaan soal dengan terburu-buru.

Permasalahan pendidikan matematika berupa sulitnya menyelesaikan soal cerita tersebut dapat diminimalisir dengan menerapkan strategi pembelajaran yang berorientasi pada upaya bagi siswa untuk : (a) membangun sikap dan persepsi positif terhadap belajar dan terhadap matematika sebagai obyek belajar, (b) memperoleh dan mengintegrasikan pengetahuan matematika, (c) memperluas (mengembangkan) dan memperbaiki pengetahuan matematika yang telah dimiliki (d) mampu menggunakan pengetahuan matematika yang dimiliki baik dalam belajar matematika, ilmu-ilmu lain, maupun dalam kehidupan sehari-hari (e) membangun kebiasaan berfikir produktif. (e) Menggunakan pendekatan pembelajaran yang bersifat aplikatif seperti CTL, PMRI dan pembelajaran kooperatif.

\section{KESIMPULAN DAN SARAN}

Berdasarkan pembahasan hasil penelitian disimpulkan beberapa letak kesalahan, jenis kesalahan, dan penyebab kesalahan siswa dalam menyelesaikan

soal cerita di kelas IV SD khususnya SD Negeri 4 Yosodadi, yakni:

1. Letak kesalahan yang dilakukan subjek penelitian dalam 
menyelesaikan soal cerita adalah membuat model/kalimat matematika, menyelesaikan model atau kalimat matematika, dan menuliskan jawaban akhir dari soal.

2. Jenis kesalahan yang dilakukan subjek dalam menyelesaikan soal cerita adalah kesalahan konsep dan prinsip.

3. Faktor penyebab sehingga melakukan kesalahan dalam menyelesaikan soal cerita yakni:

- Salah menafsirkan soal kedalam rumus yang digunakan untuk membuat kalimat matematika

- Belum memahami model atau kalimat matematika

- Penguasaan konsep prasyarat yang belum matang

- Kurang baik dalam pemahaman memaknai soal dan membaca

- Penalaran yang kurang baik dalam menerjemahkan maksud dan arah soal

- Kesan negatif terhadap soal-soal cerita yang dipandang menakutkan dan

- membuat malas siswa untuk membaca soal

- Tidak teliti atau cermat dalam membaca dan cenderung ceroboh dalam pengerjaan operasi pada soal.

Menginat peran pendidikan matematika di sekolah dasar sangat penting bagi pendidikan dan kehidupan siswa di kemudian hari dan berdasarkan kesimpulan penelitian di atas dapat dikemukakan saran sebagai berikut:

1. Hendaknya siswa mulai sejak dini diperkenalkan masalah yang bersifat aplikatif dalam kehidupan sehari-hari yang dituangkan dalam bentukbentuk soal cerita.

2. Guru hendaknya mampu memberikan konsep pemahaman dan nalar dalam matematika dengan menggunakan beberapa macam pendekatan bersifat riil dan aplikatif dalam kehidupan yang berdampak pada penyelesaian soal-soal cerita matematika.

3. Menanamkan kesan yang baik dan positif pada soal-soal cerita sebagai tipe soal yang menyenangkan dan menarik.

4. Bagi para insan pendidikan hendaknya lebih sering melakukan penelitian-penelitian pendidikan matematika sehingga problematika pendidikan matematika di Indonesia dapat terungkap.

\section{DAFTAR PUSTAKA}

Ahmad. Azizah, Tarmizi, R.A, and Nawawi. M. (2010). Visual representation in Mathematical Word Problem Solving Among Form Four Students in Malacca. Procesia Social and Behavioral Education Science. 2 (8), 356-361.

Bosse, M.J., Gyamfi, K.A., and Cheetham M.R.. (2012). Assessing the Diffculty of Mathematical Translation: Synthesizing the Literature and Nodel Finding, International Electronic Journal of Mathematics Education, 6 (3). 113133.

Huang, dkk. (2012). “ Learning Achievement in Solving Word Based Mathematical Questions throught a Computer Assisted Learning System", Educational Technology and Society Jurnal, 15 (1), 248- 259.

Otilia, Barbu. (2010). "Effects of Linguistic Complexity and Math Difficulty on Word Problem Solving by English Learners", International Journal of Education, 2 (2), 1-19. 
e-ISSN 2442-5419 Vol. 5, No. 2 (2016) 161-171

p-ISSN 2089-8703

Polya. (2007). Langkah-Langkah

Penyelesaian Soal Cerita Soal.

Diakses tanggal 14 Juni 2016 dari

http://id.shvoong.com/writing-and-

speaking/2174905-langkah-

langkahpenyelesaian-soal-

cerita/\#ixzz1xs02LD82.

Sukmadinata, Nana Syaodih. (2011).

Metode Penelitian Pendidikan.

Bandung: PT Remaja Rosdakarya. 